\title{
文獻に見られるインド繪畫の分類
}

\section{—Viṣnudharmottara-purāṇa を中心として—}

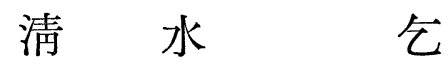

古代，中世を通じて，繪畫に言及している文獻は多數あるが，具體的に，繪畫 の樣相を傳えるものは，極めて，少ないといわなければならない。

ここに, 中心として取りあげた Viṣnudharmottara-purăṇa (以下 V. Dh.) 41章 は 4 種の繪畫をあげこれについて具體的な說明を行なつている點で，インド美術 に關する文獻の中でも，極めて，重要であり，且つ，異彩を放つているものとい える。しかし，V.Dh に見られる繪畫に對する語學的な解釋は私の能力の及ぶと ころではない。從つて, 諸外國の研究者の成果を紹介し, てれに，私見を加えて 4 種の繪畫の(1)樣式の流布した地方，(2)形態，(3)內容を具體的に推定して見たい. と思う。

V. Dh. が言う繪畫の 4 種とは satya, vainika, nāgara, miśra である。この 4 種に對して，V.Dh. の說明は次の通りである。

(1) yat-kiñ-cil-lokasādṛ́śyạ̣ citram tat-satyaṃ-ucyate/ dīrghāngaṃ sapramāṇaṃ ca sukumāraṃ subhūmikam/!

『世の中のものと相似している繪畫はどれでも satyaといわれる。(形は) 細長く，正 しい尺度を有し，纖細であり，正しい素地を有している。』

(2) catur-asra susaṃpūrṇaṃ na dīrgham na-ulvaṇākṛtam/ pramāna-sthānalamba-āḍhyạ̣ vainikam tan-nigadyate// 『(形は) 四角であり，巧に仕上げられており，長くなく，過度に派手やかでない， 正しい尺度を有し，得られた姿勢は豐である。とれは vainika といわれる。』

(3) dṛ̣hha-upacita-sarvāng gạ̣ vartulam na ghana-ulvaṇam/ citram tan-nāgaram jñeyaṃ svalpa-mālya-vibhūṣaṇam//

『(形は) 丸く，極度に厚くなく，若干の花輪の飾りをつけている。との繪は nāgara

（1）使用したテキストは The Viṣnudharmottara-purāṇa Third Khaṇḍa, ed. by P. Shah. Baroda 1958. である。唒，本書の編篹年代は上限は nāṭyaśāstra の時代 下限は al-Bīrūnĩ の Tārikh al-Hind (インド誌) を下らない。郎ち $3^{\mathrm{c}} \mathrm{A} . \mathrm{D} . \sim 11^{\mathrm{e}}$ A.D. で一般的には $9^{c}$ A. D. におかれ，北インドの Śilpaśāstra と考えられ ている。

(2) Adh. 41. Ślos. 2 5a. 
と知られている。』

(4) citraṃ-miśraṃ samākhyaṃ samāsān-manujottama/

『他のものを組合せたものは miśra といわれる。人間の最たる者よ。』

以上の文章について，その解釋が外國の研究者によつてなされた。それを年代 順に見ると，

(1) 1924. Stella Kramrisch が V.Dh の譯を發表。

(2) 1931 32. A. Coomarswamy が J. A. O. S. (Journal of Americam Oriental Saciety) vols. $51 \sim 52$ に. Dh の 41 章の全譯を發表。

(3) 1933. V. Raghavan が Indian Historical Quarterly. vol. 9. (p. 898) にお いて，A. Coomarawmy に反論。

從つて, 繪畫の分類に關する問題は35年以前に提起されたのである。その後，如 何に展開したかを知らないが, 最近, 私の知る限りでは Tarpada Bhattacharyya： The Canons of Indian Art (1947. Second. Ed. 1963), Siri Gunasinghe: La Technique de la peinture Indienne (1957), D. N. Shukla; Vāstu-Śāstra. vol. 2. (1958) において部分的に論求され, 更に P. Shah : Viṣṇudharmottara-purāṇa 3rd Khạ ḍa Vol. II (1961) において從來の學說が總括的に檢討され，P. Shah の獨 自の解釋が見られる。

さて，V. Dh における繪畫の 4 種のらち問題となるものは satya, vainika, nāgara の三種である。Stella Kramrisch と A. Coomaraswamy の兩博士はとの問 題におけるパイオニヤとも云らべき人である。この兩博士の見解を次に比較して 見よら。

(1) satya：前者はこれを true to life と譯し，後者は pure or sacred と譯し ている。

(2) vainika: 兩者共に vainika を vīnaā と關連させて lyrical と譯している。

(3) nāgara：前者はとれを as of the city と譯し, 後者は satya の pure or sacred と對照させとれを urban or secular と譯している。 satya と nāgara について兩者は見解を異にしているのである。前者の satya= true to life といら譯語は V. Dh. の著者（編者?）の云ら lokasādṛ́śya から推 して贫當であり，nāgaraを nāgaraka から類推して，as of the cityと譯したの にも無理がないと思らが，後者は繪畫を聖と俗といら，いわば，宗呚的觀點から

（3）上野照夫敉授が哲學季刊第10號（pp. 85-93）にてれを和譯している。 
見ている點, V. Dh の主張一kalānāṃ pravarạ̣ citram dharma-kāma-arthamokśadam. (諸藝術のうち最良のものたる繪畫は dharma, kāma, artha, mokśa を與え るものであるーと矛盾する見解ではなかろらか。後者に對する V. Raghavan の 反論は何ら具體性は見られない。即ち，「satya, vainika, nāgara に對して A. Coomaraswamy は正しい解釋をしていない。 satya tattvikacitra と解するこ とは出來ず，又 vainika を lyre を意味する vāṇāによつて說明するととも出來 ない。同時に, nāgara は vātsyāyana の云ら nāgaraka によつて說明するとと は出來ず，建築に見られる nagara 樣式はこの解釋を助けるものではない。」と 述へ，結局，「V. Dh. 私がを讀んだ印象では V. Dh. の著者自身もこれらの正し い意味を知つていなかつた樣である。」とら樣な, V. Dh. 以前に 4 種の繪畫の 存在を暗示する表現で終つている。

次に，最も新しい見解を提示している P. Shah は satya を一般的な寫實を基 調とする繪畫として，敢て說明を加えず， vainika と nāgara に論點を絞り，そ の名稱の由來を論求している。郎ち, 「vainika は veñā から來たもので, veṇa は Dakṣināpatha 地方の河の名である。從つて, vainika はこの地方に知られて いた樣式である。これを建築樣式から見ると Drāvida 樣式に一致する。Drāvida 樣式の建築は śikhara が直線的で四角い點, vainika 樣式の繪畫のフレイムの形 と一致する。又 nāgara は nagara から來たもので, 地理的には北インドにての 中心をおくととが出來る。nagara 樣式の建築では śikhara が曲線であり，nāgara 樣式の繪畫のフレイムの形が圓い點と一致する。といら樣に, 先の兩博士 の見解に對して言及せず，且つ，V. Raghavan が否定した點を一步考察を深め て，V. Raghavan の見解を否定的飞探り入れている。

以上の三者の見解を總括すれば，次の樣に言えよら。 satya：寫實的な繪畫で，細長いフレイムを持つもの。 vainika: Dakșināpatha. 郎ち, Deccan 地方に知られ，少々派手な感じがあり， 四角 (正方型) のフレイムを持つもの。 nāgara: 北インドに知られ，圓いフレイムを持ち，てれが花輪で飾られているも

(4) Adh. 43. ślo. 39a.

（5）更に細詳には P. Shah Viṣṇudharmottara-purāṇa 3rd Khaṇda Vol. 2. pp. 119〜124 參照。

(6) A. Coomaraswamy は History of Indian and Indonesian Ant. 1927. 註 6 の 91 (山本譯: 印度及び東南亞美術史，S. 19. p. 114）で satya を寫實的とし，省像 畫, vainika を音階法の繪 nāgara を色ぽい繪とという推定をしている。 
の。

しかし，以上の結論をもつてしても，依然として，具體的に繪畫の內容を知る ことは出來ない。ただ，繪畫の形態と流布した地方を具體的に知るのみである。 私は，とこで，第 4 の miśra を考虑に入れたい。形態上 miśra を豫想するとと は些か，困難ではなかららが，描寫されるべき內容に關してのみ miśra は考え られるところである。P. Shah. が vainika, nāgra の 2 種の繪畫に彼女の論點を 置いたのはその地理的度觀點に終止したからであり, 繪畫の内容についての考虑 は拂われていない。

先ず，前揭の 4 種の繪畫に對する V. Dh の說明中，泩目す心゙き點は satya と vainika k pramāṇa 更に vainika sthāna の語が見られる點である。云らまで もなく pramāna は人體の尺度を指し， sthāna は人體の姿勢を指す。從つて， satya と vainika はその主題が秆或は人間，その他想像上のものであると考えら れよう。 sthāna と pramāṇa は繪畫の 8 guṇa $の$ 第 1 , 第 2 に揭げられているも ので silpin が繪畫制作上，必らず，守らなければならないものである。從つて， V. Dh. は繪畫の主題に應じて尺度を規定している。例えば，人體の尺度には hamsa, bhadra, mālavya, rucaka, śaśaka, の5 種があり，神付 hamsa の尺度で。 吅掔 聖賢 vidyādhara は bhadra の尺度, kinnara, rākśasa, uraga, は mālavya の 尺度，yakśa は rucaka の尺度，人間は śaśaka の尺度で描かなければならない 樣に規定されている。

次に， satya に說かれる lokasādṛ́sya である。sãdṛśya はインド繪畫の基調と なるもので, V. Dh. は次の如く主張している。

etad-rūpa-samuddeśam-adṛṣtānām tava-īritam//

dṛșțam susadṛ́sạ̣ kāryam sarveśām-aviśeșatah/

caitre sādṛ́yakaraṇaṃ pradhānam parikīrtitam//

(7) Adh. 35. ślos. 8-18. Adh. 36. 飞詳說

(8) Adh 39. ślos. 1-36. 亿詳說

(9) Adh. 43. ślo. 19.

(10) Adh. 35. ślo. 8a.

(11) Adh. 36. ślo. 6a.

(12) Adh. 42. ślo 9a.

(13) Adh. 42. ślo. 10b.

(14) Adh 42. ślo. 11.

(15) Adh. 42. ślos. 47b-48. 
『見えないものの形は世の中に見られるものから推して表現される。總て，見えるものは， 間違なく，極めて似ている樣に作られる。繪畫において相似せるものを作るととは最も 重要なものであるといわれる。』

從つて, 私は adṛṣta なるものを Lokasādṛśya に表現したもの具體的には hamsa の尺度を用いる神を主題としている繪畫が satya であると考える。vainika は haṃsa 以外の尺度が用いられ，必らずしも， lokasādṛ́sya を要求されない種 々の Sthāna をした kinnara, rākśasa, yakṣa の如き想像上のものや，人間を主 題としたものであろら。次に，nāgara であるが V. Dh. の說明からは何の手脚り を得るととが出來ない。この樣式の繪畫では pramāṇa や sthāna に言及してい ない點から推して，V.Dh. がその描寫法を規定している。 nagara (都會) grama (村) paṇya-yukta (村場) āpana-bhūmi (酒場) 等 p ākāśa (空) bhumi (地) parvata（丘）vana（森）等の自然, ratri (夜) prāgrātri（宵の口） sāruṇa（早朝） tamas (闇) 等一日の典型的な時刻や其他のものを主題としたもので，いわば， 風景繪や rātri, prāgrātri に定められている如き Erotic な繪を指すのではない かと考える。そして，とれら 3 種の繪畫の內容を組み合せたものが miśra と呼 ばれたのであろら。先に，A. Coomarswamy の譯語の問題點に觸れたが，內容 的に言つて，私の推測が誤りでなければ，博士の譯語は具體性を持つが，誤解の 惧れは十分にある。

以上をまとめて見ると次の如くになる。

\begin{tabular}{|c|c|c|c|}
\hline 類 & 形 & 流布した地方 & 題（內容） \\
\hline satya & 矩 型 & & 神 \\
\hline vainika & 正方 型 & Dccan 地方 & $\begin{array}{l}\text { 想像的なもの（kinnara, rākśasa 等) 及 } \\
\text { び,人間 }\end{array}$ \\
\hline nāgara & 圓 & 北インド & 自然の風景, Erotic な場面 \\
\hline miśra & & & 上の 3 種を組み合せたもの \\
\hline
\end{tabular}

（16）それでは「citre sādṛ́sakaraṇam pradhānam」という V. Dh. の主張との矛盾 があるとの疑問があろう。結論的には sādṛ́śya はカノンの規定を守りてれと一致す るととであるといえよう。Adh. 43. ślo. 23b で śāstrajñā は 「pratītạ ca likhedhi-imān-na-apratīteh kathañcana/」(明らかに認識されるものを描き, 決して, 認 識されないものは描かない。）といつている。sāstrajñā ととつてカノンが彼らの認 識の基調となるものであつた。しかし，南インドの論書 Abhilașitārthacintāmaṇi. ślo. 939b (mānasollāsa. ślo. 900 b) では sādṛśya は「darpanepratibimbavat」 （鏡に映じた像の如く）であるといつている。sādṛ́sya については A. Coomaraswamy: The Transformation of Nature in Art. (Dover edition,1956) pp. 11 14. に詳しい論述がある。

(17) Adh. 42. Ślos. 57-71. 